\title{
Kuivatun kanansonnan energia-, valkuais- ja kivennäisarvo märehtijöillä
}

\author{
Maija-Liisa Salo, Marjatta Suvitie ja Matti Näsi \\ Yliopiston kotieläintieteen laitos, Helsinki 71
}

\section{Energy, protein and mineral value of dried poultry manure for sheep}

\author{
Maija-Liisa Salo, Marjatta Suvitie and Matti Näsi \\ Department of Animal Husbandry, University of Helsinki, $00710 \mathrm{Helsinki}$
}

\begin{abstract}
The energy, protein and mineral value of the dried manure of laying battery hens (DPM) was investigated in digestibility and balance trials with four adult sheep. The basal diet consisted of barley meal and straw supplemented with vitamins and minerals. In one of the two trials $13 \%$ of DPM, with a nitrogen content of $6.7 \%$ of dry matter, was incorporated into the diet. The intake of energy corresponded to the maintenance requirement. In the DPM diet the intake of crude protein and some minerals exceeded the requirement.

The digestibility of the organic matter of DPM, calculated by the difference-method, was $62.8 \%$ and that of total nitrogen $88.4 \%$. The energy value was 1.58 Mcal. ME or 0.47 F.U. (F.U. $=0.7$ starch units) per $\mathrm{kg}$ dry matter, and the nitrogen value $650 \mathrm{~g}$ DCP per F.U. The animals were in balance in respect to nitrogen and most of the minerals, and no obvious differences were found between the diets.
\end{abstract}

Kotieläinten lannan hävittämisestä on monissa maissa muodostunut vaikea ongelma ja eräänä sen ratkaisuna on tutkittu lannan kuivaamista eläinten rehuksi. Arvokkainta on kananlanta, koska se sisältää sekä sonnan että virtsan ja siten pääosan rehun typestä ja kivennäisaineista. Ruokintakokeissa kanansonta onkin todettu märehtijöille hyvin sopivaksi rehuksi (esim. Thomas ym. 1971, Rohde 1971, Blair ja KNight 1973). Rehutaulukoista ei kuitenkaan löydy energia-arvoa sen paremmin puhtaalle kanansonnalle kuin kuivikkeita sisältävälle pehku- tai broilerlannallekaan. Ruokintakokeidenkin yhteydessä energia-arvo on määritetty vain aniharvoissa tutkimuksissa (LowMAn ja KNight 1970 pässeillä; Shannon ym. 1973 ja Harnisch 1974 kanoilla). Tämän tutkimuksen tarkoituksena oli selvitellä kuivikkeettoman munivien kanojen sonnan energia-, valkuais- ja kivennäisarvoa märehtijöillä. 


\section{Kokeiden järjestely}

Neljällä täysikasvuisella pässillä suoritettiin aluksi sulavuus- ja tasekoe perusrehulla ja sen jälkeen koe, jossa dieettiin sisällytettiin $13 \%$ kuivattua kanansontaa. Perusrehun muodostivat ohrajauho ja olki. Kanansonta kerättiin päivittäin Viikin koetilan häkkikanalasta. Se kuumennettiin aluksi $120^{\circ} \mathrm{C}$ lämpötilassa ja kuivattiin $100^{\circ}$ :ssa ja jauhettiin. Koerehujen koostumus selviää taulukosta 1 .

Pässit olivat koehäkeissä ja niillä oli sulavuuskoevaljaat. Rehu annettiin kahdesti päivässä ja samalla tyhjennettiin sontapussit. Sonnasta määritettiin päivittäin kuiva-ainepitoisuus $100^{\circ}$ :ssa ja määräosa kuivattiin analyysinäytteeksi vakuumissa $50^{\circ}$ :ssa. Virtsa valui astiaan, jossa typpihäviöiden estämiseksi oli rikkihappoa. Virtsa mitattiin päivittäin ja määräosa otettiin analyysinäytteeksi.

Rehumäärä oli laskettu ylläpitotarvetta vastaavaksi. Peruskokeessa pässit saivat $750 \mathrm{~g}$ ohrajauhoa, $75 \mathrm{~g}$ olkea, $20 \mathrm{~g} \mathrm{Ca}_{3}\left(\mathrm{PO}_{4}\right)_{2}, 4 \mathrm{~g} \mathrm{NaCl}$ ja $5 \mathrm{~g}$ vitamiiniseosta päivässä. Kanansontakokeessa määrät olivat $710 \mathrm{~g}$ ohraa, $71 \mathrm{~g}$ olkea, $115 \mathrm{~g}$ kanansontaa, $2.5 \mathrm{~g} \mathrm{NaCl}$ ja $5 \mathrm{~g}$ vitamiiniseosta. Vettä oli vapaasti. Valmistava kausi kesti kaksi viikkoa ja keruukausi peruskokeessa 8 päivää ja kanansontakokeessa 14 päivää.

Viralliseen rehuanalyysiin kuuluvat määritykset suoritettiin standardimenetelmillä, virtsahappo Praetorius'in (HyvärINEN ym. 1972, s. 410) menetelmällä,

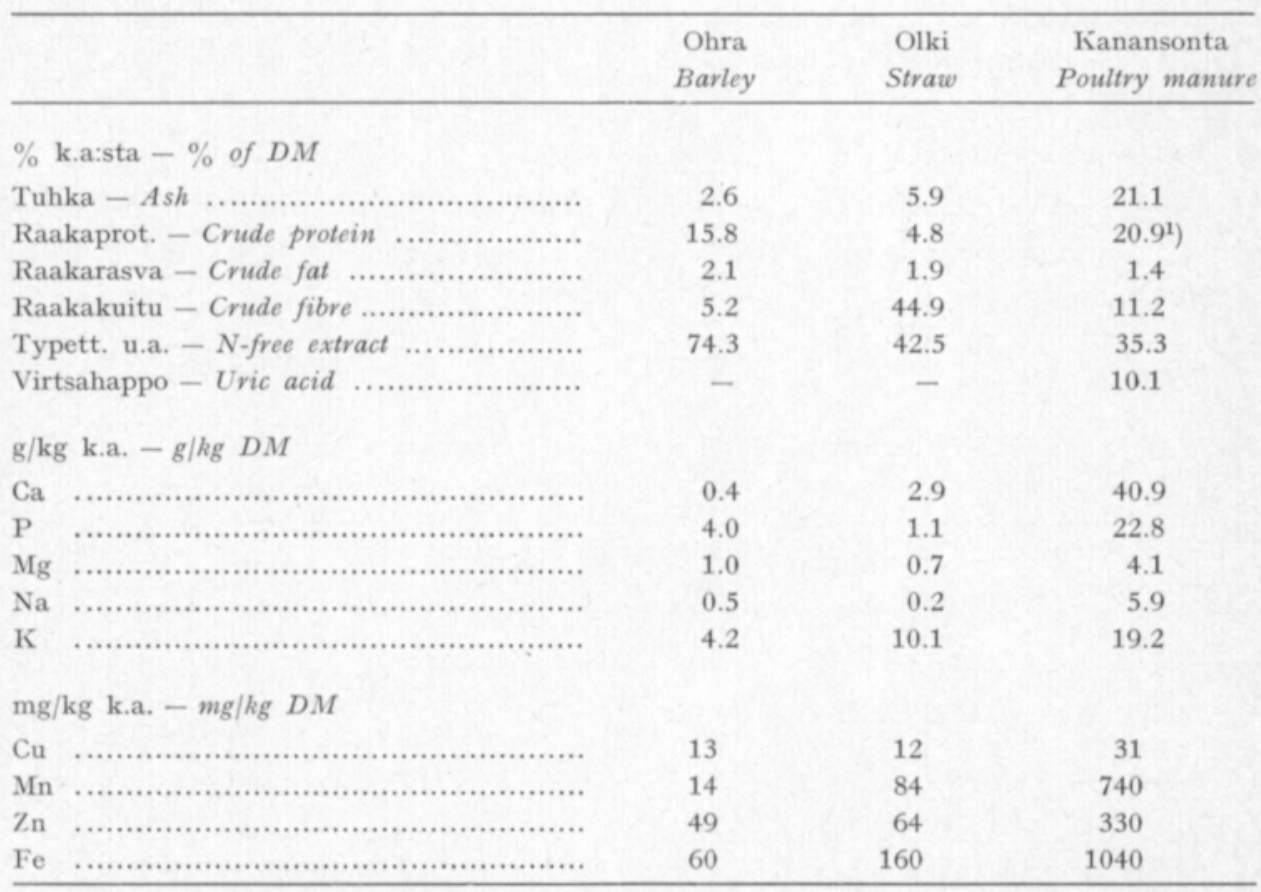

1) (Kokonais-N - virtsahappo-N) $\times 6.25-($ Total $N-$ uric acid $N$ ) $x 6.25$. 
tärkkelys SALOn ja SALMEN (1968) menetelmällä, kationit AA-1000 Techtron atomiabsorptiospektrofotometrillä ja fosfori TAUsskyn ja SHorkin (1953) menetelmällä.

\section{Tulokset ja tarkastelu}

Taulukossa 2 esitetään keskimääräiset sulavuustulokset perusdieetistä, kanansontadieetistä ja differenssinä laskettuna kanansonnasta. Kanansonnan raakaproteiinipitoisuus laskettiin siten, että kokonaistypestä vähennettiin virtsahapon typen osuus ja jäännös muunnettiin raakaproteiiniksi kertoimella 6.25. Typettömät uuteaineet saatiin kaavasta $100-$ (tuhka + virtsahappo + raakaproteiini + raakakuitu + raakarasva), kaikki laskettuna kuiva-aineesta.

Kokeessa todettu orgaanisen aineen sulavuus on samaa luokkaa mitä Lowman ja Knight (1970) ja Tinnemit ym. (1972) ovat todenneet. Thomasin (1970) saama tulos on korkeampi. Pässit olivat sulatuskyvyltään epätasaisia, kuten standardipoikkeamista voidaan nähdä.

Kanansonnan typen sulavuus osoittautui erittäin hyväksi, kokonaistypen sulavuus oli peräti $\mathbf{8 8 . 4 \%}$. Raakaproteiinin sulavuus (taul. 2) laskettiin siten, että virtsahappo katsottiin täysin sulavaksi. Myös ulkomaisissa tutkimuksissa typen sulavuus on todettu hyväksi (SMrTH 1974).

Typettömien uuteaineiden sulavuus oli suhteellisen heikko. Tällainen tulos oli kuitenkin odotettavissa, koska kanansonnan uuteaineet koostuvat pääasiassa hemiselluloosasta ja ligniinista; tärkkelystä ja sokeria on vain $1-2 \%$ kuivaaineesta (taul. 3).

Raakakuidun heikonlainen sulavuus oli niinikään odotettavissa, sillä kuitu on pääasiassa peräisin jyvien kuoriosista ja siten ksylaania ja selluloosaa.

Raakarasvaa kanansonnassa on niin vähän, että sen sulavuudella ei ole merkitystä rehuarvolle.

Energia- ja srv-arvo

Energia-arvoa laskettaessa virtsahapon arvoksi katsottiin nolla. Sulavat aineet muunnettiin energiamääriksi rehuille tarkoitettujen ry- ja ME-kertoi-

Taulukko 2. Dieettien ja differenssinä laskien kanansonnan sulavuudet, \%.

Table 2. Digestibilities of diets and of dried poultry manure calculated by difference, $\%$.

\begin{tabular}{lccc}
\hline & $\begin{array}{c}\text { Perusdieetti } \\
\text { Basal diet }\end{array}$ & $\begin{array}{c}\text { Koedieetti } \\
\text { Exp. diet }\end{array}$ & $\begin{array}{c}\text { Kanansonta } \\
\text { Poultry manure }\end{array}$ \\
\hline Org. aine - Organic matter $\ldots \ldots .$. & $81.8 \pm 3.06$ & $79.6 \pm 1.22$ & $62.8 \pm 10.50$ \\
Raakaprot. - Crude protein ....... & $79.5 \pm 6.58$ & $79.1 \pm 2.01^{1}$ ) & $76.9 \pm 10.91^{1}$ ) \\
Raakarasva - Crude fat ......... & $82.4 \pm 4.80$ & $76.4 \pm 4.71$ & $33.1 \pm 22.24$ \\
Raakakuitu - Crude fibre ......... & $41.8 \pm 6.18$ & $39.7 \pm 2.64$ & $31.7 \pm 13.87$ \\
Typett. u.a. - N-free extract ..... & $87.1 \pm 2.00$ & $84.9 \pm 0.84$ & $57.5 \pm 11.32$ \\
\hline
\end{tabular}

1) Kokonais-N - virtsahappo-N; virtsahapon sulavuudeksi katsottu $100 \%$ - Total N-uric acid $N$; uric acid taken as $100 \%$ digestible. 
mien avulla (NJF:n rehutaulukot, 1969). Laskemalla saatu ry-arvo korjattiin kuitukorjauksella. Energia-arvoksi märehtijöillä saatiin seuraavat luvut:

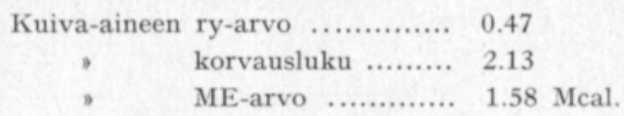

Jos kuivatussa sonnassa on $10 \%$ vettä, on ry-arvo 0.42 , korvausluku 2.4 ja ME-arvo 1.4. Keskiluokan heinässä vastaavat luvut ovat $0.44,2.3$ ja 1.76 . ME-arvon mukaan arvostellen kanansonta on melko paljon heinää vähäarvoisempaa. Ry-arvossa ero on pieni, koska kuitukorjaus jää vähän kuitua sisältävässä kanansonnassa alhaiseksi.

Kanansonnan energia-arvoon vaikuttavat lähinnä typettömien uuteaineiden ja raakaproteiinin pitoisuudet ja sulavuudet. Kuidun merkitys on vähäinen ja rasvan melkein olematon. Kanansonnalle ominainen korkea tuhkapitoisuus alentaa energia-arvoa.

Lowman ja KNITHT (1970) ovat määrittäneet kanansonnan sulavan energian arvon pässeillä ja siitä kertoimella (0.82 tai 0.74$)$ muuntokelpoisen energian arvon. Jälkimmäinen kerroin antaa ME-arvoksi saman tuloksen (1.57 Mcal.) kg k.a.), mikä tässä kokeessa saatiin tavanomaisten rehujen laskumallia käyttäen. Analyysituloksistakin päätellen heidän tutkimansa kanansonta oli tässä tutkitun kanssa varsin samanarvoista. SHannon ym. (1973) ovat todenneet häkkikanojen sonnan ME-arvoksi munivilla kanoilla keskimäärin $0.97 \mathrm{Mcal}$./ kg k.a. ja Harnisch (1974) $1.18 \pm 0.14$ Mcal. $/ \mathrm{kg}$.

Kanansonnan arvo märehtijäin rehuna perustuu ratkaisevasti sen typpisisältöön ja typen hyväksikäyttöön. Typpipitoisuus riippuu kananrehun raakaproteiinipitoisuudesta sekä tietyssä määrin myös rehun sulavuudesta. Taulukossa 3 nähdään rehun koostumuksen vaikutus sonnan koostumukseen. Luvut ovat munivilla kanoilla suoritetusta kokeesta, jossa vertailtiin erilaisia häkkikanojen täysrehuja. N:o 2 oli samaa rehuseosta, mitä kanat saivat silloin kun niiltä kerättiin sontaa sulavuuskokeeseen. Vertailusta käy ilmi että kanansonnan typpipitoisuuteen vaikuttaa rehun raakaproteiinipitoisuuden ohella sen kuitu- ja tärkkelyspitoisuus, koska niistä riippuu paljolti rehun sulavuus.

Sulavuuskokeessa käytetyn kanansonnan typpipitoisuutta nosti pienessä määrin myös kanojen alhainen munintaprosentti (sonta kerättiin vasta mu-

Taulukko 3. Rehun koostumuksen vaikutus kanansonnan koostumukseen. Luvut ovat \% k.a:sta. Table 3. Effect of feed on composition of poultry manure. Figures are percentages of dry matter.

\begin{tabular}{|c|c|c|c|c|c|c|c|c|}
\hline & & & & hu - Feed & & Son & $\mathrm{a}-$ Manu & \\
\hline & & & R. prot. & R. kuitu & Tärkkelys & R. prot & R. kuitu & Tärkkelys \\
\hline & & & Cr. protein & Cr. fibre & Starch & Cr. protein & Cr. fibre & Starch \\
\hline Rehu & $-\mathrm{Fee}$ & no 1 & 21.3 & 5.7 & 31.6 & 36.9 & 14.4 & 1.4 \\
\hline , & , & , 2 & 20.8 & 4.6 & 36.6 & 41.7 & 14.3 & 1.7 \\
\hline , & - & - 3 & 19.2 & 6.0 & 30.9 & 34.2 & 15.7 & 1.0 \\
\hline , & - & , 4 & 16.4 & 6.0 & 34.2 & 27.6 & 17.3 & 1.5 \\
\hline
\end{tabular}


ninnan alussa olevilta nuorikoilta) sekä sonnan kuivaaminen päivittäin, mikä teki typpihäviöt pieniksi.

Jos kanansonnan srv-arvo lasketaan kokonaistypen sulavuuskertoimen mukaan, saadaan tulokseksi 786 srv/ry. Oikeampi menetelmä lienee kuitenkin katsoa virtsahapon typen hyväksikäyttöarvoksi urean tapaan $70 \%$. Sen mukaan laskien kanansonta sisälsi $654 \mathrm{~g}$ srv/ry.

Sulavuuskoe ja samoin kananrehun ja -sonnan typpipitoisuuden vertailu suoritettiin silloin, kun tehtaat eivät vielä olleet alentaneet täysrehujen raakavalkuaisprosenttia. Kokeen kanansonta antoi sen vuoksi liian hyvän kuvan lähitulevaisuuden kanansonnan raakaproteiiniarvosta. Taulukon 3 tulosten perusteella voidaan päätellä, että jos kananrehun raakaproteiinipitoisuus alennetaan 14.5-15\%:n tasolle (n. 16-17 \% k.a:sta), laskee kanansonnan raakaproteiinipitoisuus alle $30 \%$ :n. Kuiva-ainekilon srv-määrä alenee silloin nyt todetusta yli 300 grammasta noin 200 grammaan, ehkä allekin. Kuitenkin kuivattu kanansonta sisältää silloinkin noin $450-500 \mathrm{~g}$ srv/ry.

Kanansonnan kivennäisarvo on korkea (taul. 1). Sulavuuskokeessa pässien dieettiin sisältyi kanansontaa $13 \%$ ja kivennäislisänä annettiin ainoastaan ruokasuolaa. Vajausta muodostui vain kalsiumista (79\% dieetistä oli ohraa). Hivenaineita kanansontayhdistelmä sisälsi suuren ylimäärän (taul. 5).

Typpi- ja kivennäistase

Typpitase esitetään taulukossa 4. Rehuyhdistelmien raakaproteiinipitoisuus oli peruskokeessa $13.4 \%$ ja kanansontakokeessa $16.6 \%$ eli pitoisuudet ylittivät runsaasti ylläpitotarpeen. Energian saanti oli laskettu niukan ylläpitotarpeen mukaan. Koska koe-eläimet lisäksi olivat täysikasvuisia, ei mainittavaa typen varastointia ollut odotettavissa. Peruskokeen typpitase muodostui keskimäärin hiukan negatiiviseksi, kanansontakokeen vähän positiiviseksi. Kummankin kokeen aikana erittyneestä typestä noin $80 \%$ erittyi virtsassa.

Kivennäistaseet nähdään taulukossa 5. Kummassakin kokeessa eläimet olivat useimpien kivennäisten kohdalla tasapainossa. Kalsiumtase vaihteli saannin mukaan, sen sijaan melko suuri mangaani-vajaus peruskokeessa ei vaikuttanut taseeseen. Hivenaineiden runsas saanti kanansontakokeessa ei saanut aikaan niiden varastoitumista. Kokeessa todettiin, että hivenaineet erittyivät lähes kokonaan ja fosfori ja kalsium pääosaltaan sonnassa. Magnesiumista erittyi virtsassa noin $45 \%$ ja natriumista ja kaliumista $70-75 \%$. Dieetillä ei näihin lukuihin ollut vaikutusta.

Taulukko 4. Typpitaseet.

Table 4. Nitrogen balances

Perusdieetti Koedieetti

Basal diet Exp. diet

Saanut N, g/pv ............ $17.3 \quad 24.0$

Intake of $N$, g/day

Pidättynyt $\mathrm{N}, \mathrm{g} / \mathrm{pv} \quad \ldots \ldots . . \quad-0.21 \pm 1.68+1.17 \pm 0.84$

Retention of $N$, g/day 
Taulukko 5. Kivennäistaseet.

Table 5. Mineral balances.

\begin{tabular}{|c|c|c|c|c|c|c|c|c|}
\hline & $\mathrm{Ca}$ & $\mathrm{P}$ & $\mathrm{Mg}$ & $\mathrm{Na}$ & K & $\mathrm{Cu}$ & Mn & $\mathrm{Zn}$ \\
\hline Saanut - Intake & \multicolumn{8}{|c|}{$\%$ tarpeesta $-\%$ of requirement ${ }^{1}$ ) } \\
\hline Perusdieetti - Basal diet ....... & 125 & 122 & 90 & 130 & & 165 & 45 & 90 \\
\hline Koedieetti - Exp. diet ........... & 77 & 93 & 136 & 130 & & 330 & 270 & 160 \\
\hline Tase - Balance & \multicolumn{5}{|c|}{$\mathrm{g} / \mathrm{pv}-\mathrm{g} / \mathrm{day}$} & \multicolumn{3}{|c|}{$\mathrm{mg} / \mathrm{pv}-m g /$ day } \\
\hline Perúsdieetti - Basal diet ....... & $\begin{array}{l}+1.70 \\
\pm 0.29\end{array}$ & $\begin{array}{l}+1.36 \\
\pm 0.50\end{array}$ & $\begin{array}{l}+0.05 \\
\pm 0.05\end{array}$ & $\begin{array}{l}+0.48 \\
\pm 0.11\end{array}$ & $\begin{array}{l}+0.14 \\
\pm 0.62\end{array}$ & $\begin{array}{l}-0.5 \\
\pm 1.7\end{array}$ & $\begin{array}{l}+1.8 \\
\pm 1.0\end{array}$ & $\begin{array}{l}+3.3 \\
\pm 1.3\end{array}$ \\
\hline Koedieetti - Exp. diet ........... & $\begin{array}{l}-0.99 \\
\pm 0.59\end{array}$ & $\begin{array}{l}+0.73 \\
\pm 0.91\end{array}$ & $\begin{array}{l}+0.01 \\
\pm 0.04\end{array}$ & $\begin{array}{l}+0.51 \\
\pm 0.29\end{array}$ & $\begin{array}{l}-0.08 \\
\pm 0.71\end{array}$ & $\begin{array}{l}+4.3 \\
\pm 1.0\end{array}$ & $\begin{array}{l}+3.0 \\
\pm 10.1\end{array}$ & $\begin{array}{l}+4.0 \\
\pm 6.5\end{array}$ \\
\hline
\end{tabular}

1) A.R.C. (1965) normien mukaan - According to norms of A.R.C. (1965).

\section{Yhteenveto}

Munivien kanojen kuivatun sonnan energia-, valkuais- ja kivennäisarvoa tutkittiin sulavuus- ja tasekokeella neljällä täysikasvuisella pässillä. Peruskokeessa rehuna oli ohra ja olki sekä tarpeelliset kivennäis- ja vitamiinitäydennykset. Toisessa kokeessa dieettiin sisältyi $13 \%$ kanansontaa, joka sisälsi typpeä $6.7 \%$ k.a:sta. Energiansaanti vastasi ylläpitotarvetta. Raakaproteiinin ja monien kivennäisten saanti ylitti kanansontakokeessa normien mukaisen tarpeen.

Kanansonnan orgaanisen aineen sulavuudeksi saatiin differenssinä laskien $62.8 \%$ ja kokonaistypen sulavuudeksi $88.4 \%$. Energia-arvoksi tuli $\mathbf{1 . 5 8}$ Mcal. ME tai 0.47 ry/kg k.a. ja N-arvoksi $650 \mathrm{~g}$ srv/ry. Typen ja useimpien kivennäisten suhteen eläimet olivat tasapainossa eikä dieettien välillä ilmennyt selvää eroa. 


\section{KIRJALLISUUTTA}

Blair, R. \& Knight, D. W. 1973 Recycling animal wastes. Part 2. Feeding recycled wastes to poultry and livestock. Feedstuffs $45,12: 31-36$.

Harnisch, S. 1974. Energie- und Stickstoffumsatz nach Verfütterung von Geflügel-Trockenkot an Legehennen. Arch. Geflügelk. 38:1-4.

Hyvärinen, A., Jännes, J. ,Nikkilä, E., SAris, N.-E. \& Vuopio, P. 1972. Kliiniset laboratoriotutkimukset. 158 p. Porvoo-Helsinki.

Lowman, B. G. \& KNight, D. 1970. A note of the apparent digestibility of energy and protein in dried poultry excreta. Anim. Prod. 12: 525-528.

NJF. 1969 Fodermiddeltabel. 40 p. Gjøvik.

RoHDE, E. 1971. Gute Ergebnisse mit getrocknetem Hühnerkot in der Futterration von Mastbullen. Tierzucht 25:418-419.

Salo, M-L. \& SAlmi, M. 1968. Determination of starch by the amyloglucosidase method. J., Scient. Agric. Soc. Finl. 40: 38-45.

Shannon, D. W. F., Blair, R. \& LeE, D. J. W. 1973. Chemical and bacteriological composition and the metabolizable energy value of eight samples of dried poultry waste produced in the United Kingdom. 4th Europ. Poult. Conf., London, 487-494.

Sмrтн, L. W. 1974. Dried poultry manure used as sheep ration protein supplement. Feedstuffs 46: 9:32.

TAussky, H. Н. \& ShorR, Е. 1953. A micro-colorimetric method for the determination of inorganic phosphorus. J. Biol. Chem. 202: 675-685.

Тномаs J. W. 1970. Acceptability and digestibility of poultry and dairy wastes by sheep. Mich. Agr. Exp. Sta. Res. Rep. 117: 42-44.

Thomas, J. W., Yu YU, Tinnimitr, P. \& Zindel, H. C. 1971 . Dehydrated poultry waste as a feed for milking cows and growing sheep. J. Dairy Sci. 55: 126-1265.

Trnnimit, P., Yu Yu, McGuffeY, K. \& Thomas, J. W. 1972. Dried animal waste as a protein supplement for sheep. J. Anim. Sci. 35:431-435. 